\title{
"Existing organizational culture typologies and organizational commitment at a selected higher education institution in South Africa"
}

\begin{tabular}{|c|c|}
\hline AUTHORS & $\begin{array}{l}\text { Ndlovu Wiseman } \\
\text { Hlanganipai Ngirande } \\
\text { Sam Tlou Setati }\end{array}$ \\
\hline ARTICLE INFO & $\begin{array}{l}\text { Ndlovu Wiseman, Hlanganipai Ngirande and Sam Tlou Setati (2017). Existing } \\
\text { organizational culture typologies and organizational commitment at a selected } \\
\text { higher education institution in South Africa. Investment Management and } \\
\text { Financial Innovations, 14(2-1), 242-251. doi:10.21511/imfi.14(2-1).2017.09 }\end{array}$ \\
\hline DOI & http://dx.doi.org/10.21511/imfi.14(2-1).2017.09 \\
\hline RELEASED ON & Monday, 24 July 2017 \\
\hline RECEIVED ON & Tuesday, 07 June 2016 \\
\hline ACCEPTED ON & Monday, 12 June 2017 \\
\hline LICENSE & $\begin{array}{l}(c) \text { EY-NG } \\
\text { This work is licensed under a Creative Commons Attribution-NonCommercial } 4.0 \\
\text { International License }\end{array}$ \\
\hline JOURNAL & "Investment Management and Financial Innovations" \\
\hline ISSN PRINT & $1810-4967$ \\
\hline ISSN ONLINE & $1812-9358$ \\
\hline PUBLISHER & LLC "Consulting Publishing Company "Business Perspectives" \\
\hline FOUNDER & LLC "Consulting Publishing Company "Business Perspectives" \\
\hline
\end{tabular}

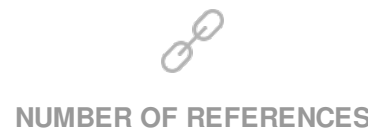

55
NUMBER OF FIGURES

0

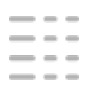

NUMBER OF TABLES

2

(C) The author(s) 2022. This publication is an open access article. 


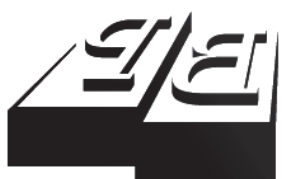

BUSINESS PERSPECTIVES

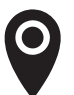

LLC "CPC "Business Perspectives" Hryhorii Skovoroda lane, 10, Sumy, 40022, Ukraine

www.businessperspectives.org

Received on: $7^{\text {th }}$ of June, 2016 Accepted on: $12^{\text {th }}$ of June, 2017

(C) Ndlovu Wiseman, Hlanganipai Ngirande, Sam Tlou Setati, 2017

Ndlovu Wiseman, Department of Human Resource Management \& Labor Relations, University of Venda, South Africa.

Hlanganipai Ngirande, Department of Human Resource Management \& Labor Relations, University of Venda, South Africa.

Sam Tlou Setati, Department of Human Resource Management \& Labor Relations, University of Venda, South Africa.
Ndlovu Wiseman (South Africa), Hlanganipai Ngirande (South Africa), Sam Tlou Setati (South Africa)

\section{EXISTING ORGANIZATIONAL CULTURE TYPOLOGIES AND ORGANIZATIONAL COMMITMENT AT A SELECTED HIGHER EDUCATION INSTITUTION IN SOUTH AFRICA}

\begin{abstract}
The study investigates the relationship between organizational culture and organization commitment at a higher education institution in South Africa. Quantitative research approach was used and 30 participants were chosen at random from academic and non-academic employees of the university. Furthermore, in order to gather data, the study used a structured questionnaire regarding the effects of existing organizational culture on organizational commitment. Pearson correlation analysis was used to determine the relationship between existing organizational culture typologies and facets of organizational commitment. The study revealed that different culture typologies bring about different levels of organizational commitment. Moreover, support of culture had a strong significant relationship with normative and continuance commitment. This means that if the organization shows the sense care and support to its employees, they will develop an obligatory sense of belonging and help the organization in attaining its objectives.
\end{abstract}

\section{Keywords}

JEL Classification organizational culture, organizational commitment, role culture, power culture, achievement culture, support culture, higher education institution

M12, M14

\section{INTRODUCTION AND THE BACKGROUND TO THE STUDY}

The major emphasis in HEIs (Higher Education Institutions) is to continuously improve the quality of education and research. This connotes higher education performance and its influence on the ranking of universities across the globe. Therefore, it is important to note factors that contribute to organization performance. Hence the performance of organization depends strongly on how things are done in that particular institution (Alvesson, 2013). The way of doing things detects the outcomes and how the organization is going to address its challenges on day to day basis. Mullins (1999) defines organizational culture as "the collection of traditions values, beliefs, policies, and attitudes that constitute a pervasive context for everything one does and thinks in an organization" (p. 53). Schein (2010) defines organizational culture as "a pattern of shared basic assumptions learned by a group as it solved its problems of external adaptation and internal integra- 
tion, which has worked well enough to be considered valid and, therefore, to be taught to new members as the correct way to perceive, think and feel in relation to those problems" (p. 18). Thus, organizational culture is an instrument that directs the performance of organizations (Singh, 2011). Furthermore, the uniqueness of organizational culture for each institution predicts how that organization will perform and meet its targets (Sudan \& Kumar, 2004; Robbins, Odendaal, \& Roodt, 2007; Singh, 2011).

Organizational culture coincides with organizational commitment (Pinho, Rodrigues, \& Dipp, 2014). Given that employees are well acquainted with the organizational culture, they will commit to the cause of the organization (Alvesson, 2013). Studies have shown that employees who are happy with the corporate culture, are willing to make significant strides in their endeavor to meet organizational objectives (Sudan \& Kumar, 2004; Kessuwan \& Muenjohn, 2010; Mitic, Vukonjanski, Terek, Gligorovic, \& Zoric, 2016). Organizational culture has been found to predict organizational commitment (Pinho, Rodrigues, \& Dipp, 2014). Organisational commitment goes in hand and glove with organizational culture and they both predict how an organization will perform (Shahid \& Azhar, 2013).

In line with the above, organizational culture and organizational commitment contribute significantly to the development of the success of any institution (Black, 2004; Pinho, Rodrigues, \& Dipp, 2014). Studies, have long shown how uniquely and significantly organizational culture and commitment can add to the success and competitiveness of organizations (Meyer \& Allen, 1990; Kessuwan \& Muenjohn, 2010; Shahid \& Azhar, 2013; Mitic, Vukonjanski, Terek, Gligorovic, \& Zoric, 2016). Committed employees have been found to exhibit innovation, work satisfaction, high performance and less turnover (Shahid \& Azhar, 2013). This implies that HEIs with a culture that employees can identify with and highly committed staff are strategically positioned for high performance and high achievement.

Organizational culture is the way in which things are done in any organization (Alvesson, 2013; Valencia, Valle \& Jimenez Jimmez, 2010). Therefore, if the existing organizational culture is ideal, employees will achieve greater individual performance and commitment to the organization as they feel their needs and desires are met (Pinho, Rodrigues \& Dipp, 2014). Hence, in the present study organizational culture was analyzed in the view to determine how it influences organizational commitment which will improve individual performance and consequently that of higher education institutions. The study used Harrison and Stoke (1990) culture typologies which are role, power, achievement and support culture. Thus, the study tested the effects of existing power, support, and role and achievement culture on the different facets of organizational commitment.

\section{ORGANIZATIONAL CULTURE}

Organizational culture has become an integral part of every organizational behavior studies (Van Stuyvesant Meijen, 2007; Manetje \& Martins, 2009; Brenton \& Driskill, 2010). This is a result of its influence on crucial factors that relate to organisational success such as performance and commitment (Lok \& Crawford, 2003). Presently, organizational culture has become important in organizations unlike in the past when the main focus was on organizational climate (Robbins, 2000; Ashkanasy, Wilderom, \& Peterson, 2011; Alvesson, 2013). Organizational culture gives the organization its distinct char- acter and how it deals with various challenges affecting it.

Collins and Porras (2000) reported that organizational culture refers to, "shared meaning held by members that distinguish one organization from other organization" (p. 38). On the same note, Arnold (2005) defined organizational culture "as the, distinctive norms, beliefs, principles and ways in which of behaving that combine to give each organization its distinct image" (p. 625). Organizational culture can also be seen as the set of values and principles that are shared amongst individuals in a particular organization. These values influence the way in which the members of the organization relate to one another and to the 
external environment (Black, 2004). The study used a definition by Black (2004), which articulates that from these common standards, beliefs, principles and expectations originates the accepted ways in which things are to be done in the organization. Therefore, organizational culture can be seen as a simple way in which things are done. Organizational culture encompasses activities such as methods, processes and procedures that are followed by an organization.

Decision making process, promotion processes and how the company deals with challenges are all found in the culture of the organization (Van Stuyvesant Meijen, 2007). Organizational culture is further said to impede or enhance the performance of any institution be it private or public organization (Martin, 2005; Nel, Werner, Botha, Du Plessis, Mey, Ngalo, Poisat, \& Van Hoek, 2014).

\subsection{Antecedents of organizational culture}

Chatman and Cha (1994) pointed out that organizational culture is affected by elements such as the history of the organization, its purpose, methodology, size, location, leadership and its structures. Nel et al. (2014) added that organizational culture is influenced by its primary function and technology. These predict the range and quality products and clients the organization attracts.

There are a number of organizational culture typologies and these have been proved to influence organizational commitment in positive or negative way (Meyer et al., 2010; Özşahin et al., 2013; Limpanitgul et al., 2014). Among others there are typologies which include clan, bureaucratic, entrepreneurial and market culture (Harrison \& Stokes, 1992; Hellriegel, Jackson, Slocum, Staude, Amos, Klopper, Louw, \& Oosthuizen, 2004). The present study focused on the culture typologies (role, support, achievement and power) by Harrison and Stoke (1992). These are briefly discussed below.

\subsection{Culture types according to Harrison and Stokes}

Harrison and Stokes (1992) identified four culture types which are include role, power, achievement and support oriented culture.

\subsubsection{Support culture}

Support culture is based on mutual trust between employees and the organization (Harrison \& Stokes, 1992). The type of culture states that people are viewed as human beings as opposed to machine and they need to be cared for and supported to achieve their goals (Harrison \& Stokes, 1992). A support culture oriented organization exhibits a caring and warm atmosphere where employees feel part of the organization thus enhancing commitment. Furthermore, employees in such organizations tend to work hard towards the accomplishment of the organizational goals hence high performance and development (Harmse, 2001; Van Stuyvesant Meijen, 2007). Support culture brings about quality service as "successful approaches to quality are based on small work teams" (Harrison \& Stokes, 1993, p. 23).

\subsubsection{Role culture}

"Role culture gives protection to employees and stability to the company and as people are protected from losing their jobs" (Harrison, 1993, p. 15). Under role oriented organisations, employees need to spend less time focusing their energy on themselves but rather on their work. This type of culture is tailored at dependability, rationality and consistency, employees are expected to keep up to their end of the bargain to be rewarded accordingly (Harrison \& Stokes, 1993).

\subsubsection{Achievement culture}

Achievement culture gives workers mutual vision and determination in the organization (Harrison \& Stokes, 1992; Alvesson, 2013). It is sometimes called "aligned organization" as it put its employee's behind a common vision or purpose (Martin, 2006). Achievement oriented individuals have inner organizational commitment and they tend to like their work and want to make a contribution to the society. These individuals willingly give more or go an extra mile in their organizations to meet stated objectives and they are passionate, energetic, and engaged in company's activities (Harmse, 2001).

\subsubsection{Power culture}

Power culture allows people in power to be either good or bad. Thus, the resources of the organiza- 
tion can be used to frustrate members or to make them happy. This is believed to be the tool used to control others or behaviors of employees. Power is centred on an individual or few individuals in the organization (Martin, 2005). Most crucial decisions are made by the person in power and that particular person absolute authority in almost all matters of the business. Harrison and Stokes (1992) state that an "institution that is power cultured is based on disproportion when it comes to resource allocation or access". Thus, the success of the company is strongly dependent on the capabilities of the leader(s) (Brown, 1995; Martin, 2005).

Several studies have been conducted on organizational culture and its influence on various factors in different sectors, including performance and commitment (Manetje \& Martins, 2009; Zhu, Devos, \& Fei, 2011; Ng’ang'a \& Nyongesa, 2012; Tolentino, 2013). This study explored the effects of existing organizational culture on organizational commitment at a selected South African higher education institution.

\section{ORGANIZATIONAL COMMITMENT}

Organizational commitment as defined by different authors indicates the relationship between an individual employee and the organization, attachment, identifying with the organization, the need to remain and the will to work hard to meet the organizational goals (Van Stuyvesant Meijen, 2007; Huey Yiing \& Bin Ahmad, 2009; Lo, Ramayah, Min, \& Songan, 2010). Organizational commitment has been defined as employee's strong desire to remain a member of a certain institution, his/ her willingness to put up more effort on behalf of the company to achieve more.

In addition, Nel, et al. (2011) state that organisational commitment is one of the key components to the success of an organization and it drives employees to willingly make sacrifices in pursuit of organizational goals. Studies have shown that organizational commitment has other benefits to the organization like low turnover, organizational citizenship behavior, increased satisfaction and performance that can be used to transform higher education institutions in South Africa (Riketta, 2002;
Coyle-Shapiro, Morrow, \& Kessler, 2006; Ozsahin, Zehir, Acar, \& Sudak 2013; Jonathan, 2015).

Committed employees can contribute to the organisation's overall wellbeing (McLaurine, 2008). Inter alia, it increases organizational effectiveness, reduce turnover and most importantly make things work even in circumstances were the environment is not conducive and there are limited resources (Meyer \& Allen, 1990; Shahid \& Azhar, 2013). According to Greenberg and Baron's study (as cited in Kessuwan \& Muenjohn, 2010), an organization with highly committed employees is more successful than an organization with less committed employees.

On the other hand, employees with low organizational commitment exhibit unwanted behavior such as arriving late at work, detachment and absenteeism (Ozsahin, Zehir, Acar, \& Sudak, 2013). Therefore, if employees are committed they can be on time and contribute more to the organization. This is supported by Mathieu and Zajac (1990) revealed that there is strong correlation between organisational commitment and job performance and withdrawal behavior. Thus, if employees are not committed to their work this might affect the organizational performance negatively to foster change and adapt to the dynamic environment (Ozsahin, Zehir, Acar, \& Sudak, 2013). Hence, HEI goals cannot be achieved if the employees are detached from the organization and do not identify with the institution. In the present study, the authors used organizational commitment as propounded by Allen and Meyer (1990) in which he identified three different types of commitment. These are normative, continuance and affective commitment.

\section{JUSTIFICATION OF THE STUDY}

South African government soon after the attainment of independence, engaged in numerous attempts to improve the performance of former, "black higher education institutions". One of these strategies was to merge former "white" with "black" higher education institutions in an endeavor to improve their performance (Ministry of Education, 2002). However, these 
efforts have not significantly improved their performances as expected (Badat, 2010; Higher Education, 2015). Among others, these are still confronted by several challenges such as lower graduation rate and higher dropouts, especially for first entering students (Kruger \& Ramdass, 2010; Higher Education, 2015). Additionally, this is still visible and reflected among the racial lines, which have evoked wide debate on the ways to bring about social balance.

To counter these challenges faced by the former "Historically disadvantaged institutions", it was of paramount importance to investigate the way things are done in these institutions and how this influences the employee commitment. As studies, have shown that organizational culture predicts organizational commitment, which will, in turn, propel performance of HEIs (Okechukwu, 2013; Shoaib Ch., Zainab, Maqsood, \& Sana, 2013).

\section{OBJECTIVES OF THE STUDY}

The study's overall objective was to investigate the effects of existing organizational culture on the different facets of organizational commitment (normative, affective and continuance) at a selected higher education institution in South Africa.

The specific objectives of the study were:

- To investigate the effects of power culture on organizational commitment.

- To investigate the effects of role culture on organizational commitment.

- To investigate the effects of support culture on organizational commitment.

- To investigate the effects of achievement culture on organizational commitment.

\section{Hypotheses}

H1 There is relationship between power culture and organizational commitment.
H2 There is relationship between role culture and organizational commitment.

H3 There is a relationship between support culture and organizational commitment.

H4 There is a relationship between achievement culture and organizational commitment.

\section{METHODOLOGY}

A self-administered questionnaire was used to solicit data from the participants (academic and non-academic) at the University of Venda. The study used a random sampling technique to select participants of the study. Random sampling technique reduced biasness, as each member from the selected department had an equal chance of being picked.

\subsection{Measuring instruments}

Harrison and Stokes' (1992) organizational culture questionnaire with 15 sub-statements was used to measure organizational culture. The instrument measures both existing and preferred organizational culture, however, for the purposes of this study, the existing culture was used. The tool has 4 sub-scales, which are role culture, achievement culture, power culture, and support culture orientation. All the scales were measured on a 4-point Likert scale ranging from 1-4. Thus, $1=$ strongly agree, 2 = agree, 3 = disagree and $4=$ strongly disagree. The instrument has been used by various scholars and proved to be valid and reliable (Grebe, 1997; Harmse, 2001, Van Stuyvesant Meijen, 2007; Ndlovu, 2014).

An organizational commitment questionnaire (OCQ) (Meyer \& Allen, 1990) was used to assess organizational commitment. This is an 18 items questionnaire that measures three dimensions of organizational commitment, which are normative, affective, and continuance commitment. It has 5 points Likert scale ranging from $1=$ strongly agree, $2=$ agree, $3=$ neutral, $4=$ disagree and $5=$ strongly disagree. According to Meyer and Allen (1990), this questionnaire has reliability of co-efficient alpha of 0.723 . The valid and reliable instrument has been used by many scholars in 
Table 1. Reliability of the existing organizational culture and organisational commitment

\begin{tabular}{l|c|c|c}
\hline \multicolumn{1}{c}{ Scale } & Cronbach's alpha (r) & Items & Interpretation \\
\hline Existing Achievement Culture & 0.598 & 15 & Acceptable \\
\hline Existing Power Culture (EPC) & 0.550 & 15 & Acceptable \\
\hline Existing Role Culture (ERC) & 0.678 & 15 & Good \\
\hline Existing Support Culture (ESC) & 0.634 & 15 & Good \\
Normative Commitment (NC) & 0.768 & 5 & Very Good \\
\hline Continuance Commitment (CC) & 0.519 & 3 & Acceptable \\
\hline Affective Commitment (AC) & 0.113 & 5 & Poor \\
\hline Average & 0.551 & & Good \\
\hline
\end{tabular}

testing and checking organizational commitment such as Dun, Dastoor and Sims (2012), as well as Igella (2014).

\subsection{Data analysis}

The data was then transformed into a meaningful form through using descriptive statistics to analyses personal information of the participants. Pearson correlation analysis was used to determine relationship between different organizational culture typologies and organizational commitment. The study analyses used Statistical Package for the Social Sciences program (SPSS version 23).

Simple frequency tables were employed to depict and summarise the information from the respondents (Punch, 1995). Frequency tables are tools used to show respondents scores in the distribution (Asthana \& Bhushan, 2016). In addition, the scores were further tabulated in accordance with the number of respondents in each category. Tables and graphs were used to represent the analysis from frequency distributions. This exercise enabled the study to illustrate and outline the basic features of the data collected (Sekaran, 1992; Collis \& Hussey, 2013; Asthana \& Bhushan, 2016). After the data had been analyzed using frequency tables, simple graphs were constructed and graphically illustrated (Mertens, 2014).

In the present study, the reliability of the culture and commitment questionnaire was tested and the results for Cronbach's alpha are shown in Table 1 above.
The study distributed fifty questionnaires to the randomly selected participants from both academic and non-academic of a selected school within the institution. Of the 50 distributed questionnaires, 30 usable questionnaires were collected and analyzed. This gave the study a response rate of $60 \%$, which is recommendable.

Respondents were not required to provide their details such as names and address thus ensuring their confidentiality. Furthermore, participants were informed of their rights of participation. Thus, they were informed that it is voluntary and if they do not feel comfortable in answering some or the whole questionnaire they have the right to refuse.

\section{RESULTS AND DISCUSSIONS}

The majority of the participants $9(30 \%)$ were between 1-2 and 3-4 years of service at the university and 5-6 years of service followed with 7 (23.3\%) participants. In addition, employees who had been working of the institution for less than a year were the least represented 1 (3.3\%). Males constituted the large number of the respondents 16 (53.3\%). In terms of the age, the majority $15(50 \%)$ of the participants were between the age of 31-40 years. The sample also showed that $14(46.7 \%)$ of the respondents were from academic staff and 16 (53.3\%) respondents from non-academic staff of a selected school in the university. 
Table 2. Inter correlation matrix of scores on the organizational culture typologies and organizational commitment constructs

\begin{tabular}{|c|c|c|c|c|c|c|c|c|}
\hline \multicolumn{2}{|l|}{ Category } & 1 & 2 & 3 & 4 & 5 & 6 & 7 \\
\hline \multirow{2}{*}{ 1. Power culture } & $\begin{array}{l}\text { Pearson } \\
\text { Correlation }\end{array}$ & 1 & & & & & & \\
\hline & Sig. (2-tailed) & & & & & & & \\
\hline \multirow{2}{*}{ 2. Role culture } & $\begin{array}{l}\text { Pearson } \\
\text { Correlation }\end{array}$ & .320 & 1 & & & & & \\
\hline & Sig. (2-tailed) & .085 & & & & & & \\
\hline \multirow{2}{*}{ 3. Achievement culture } & $\begin{array}{l}\text { Pearson } \\
\text { Correlation }\end{array}$ & -.029 & -.343 & 1 & & & & \\
\hline & Sig. (2-tailed) & .878 & .063 & & & & & \\
\hline \multirow{2}{*}{ 4. Support culture } & $\begin{array}{l}\text { Pearson } \\
\text { Correlation }\end{array}$ & -.288 & .009 & .067 & 1 & & & \\
\hline & Sig. (2-tailed) & .123 & .960 & .726 & & & & \\
\hline \multirow{2}{*}{ 5. Affective commitment } & $\begin{array}{l}\text { Pearson } \\
\text { Correlation }\end{array}$ & $-.678^{* *}$ & .114 & $.924^{* *}$ & .290 & 1 & & \\
\hline & Sig. (2-tailed) & .010 & .109 & .899 & .120 & & & \\
\hline \multirow{2}{*}{ 6. Normative commitment } & $\begin{array}{l}\text { Pearson } \\
\text { Correlation }\end{array}$ & -.240 & $.777^{* *}$ & .459 & $.72^{* *}$ & .210 & 1 & \\
\hline & Sig. (2-tailed) & .035 & .141 & .155 & .011 & .265 & & \\
\hline \multirow{2}{*}{ 7. Continuance commitment } & $\begin{array}{l}\text { Pearson } \\
\text { Correlation }\end{array}$ & $-.754^{* *}$ & -.531 & .130 & $.882^{* *}$ & -.157 & $-.753^{* *}$ & 1 \\
\hline & Sig. (2-tailed) & .002 & .012 & .493 & .004 & .408 & .000 & \\
\hline
\end{tabular}

Note: ${ }^{* *}$. Correlation is significant at the 0.01 level (2-tailed).

\subsection{Relationship between}

\section{organisational culture typologies and organizational commitment constructs}

Results in Table 2 show that there is strong negative and significant relationship between power culture and affective commitment $(r=-0.678 ; p=010)$. Also, power culture have strong negative relationship with continuance commitment $(r=-0.754 ; p=.002)$. This is indicated by $p$ value that is less than 0.01 in both cases. Thus, the increase in the power culture will result in decrease in affective and continuance commitment. On the other hand, the results show that there is negative and weak relationship between power culture and normative commitment $(r=-0.240 ; p=0.35)$, however, the $p$ value illustrates that there is less significance in the relationship, as the $p$ value is more than 0.01 . Based on the hypothesis above that there is a relationship between power culture and organizational commitment constructs, we, therefore, accept the two assumptions that there is relationship between power culture and affective and continuance commitment. On the other hand, we reject the assumption that there is relationship between power culture and normative commitment.

Furthermore, results show that there is positive relationship between role culture and affective commitment $(r=114 ; p=0.109)$ 
and role culture and normative commitment $(r=0.777 ; p=0.141)$. However, the relationship is much stronger between role culture and normative commitment shown by the $r$ value that is closer to 1 . The $p$ value in both cases is greater than 0.01 , hence there is no statistical significance of the relationship between role culture and affective commitment and role culture and normative commitment. In addition, Table 2 shows that there is moderate negative relationship between role culture and continuance commitment, however, with less statistical significance $(r=-0.531 ; p=0.012)$. Given the results above, we, therefore, accept the hypothesis that there is a relationship between role culture and normative and affective commitment, however, reject the relationship between role culture and continuance commitment.

Achievement culture and affective commitment have strong positive relationship with no or less statistical significance $(r=0.924 ; p=0.899)$. Therefore, the relationship between the two cannot be relied upon, as they have less or no statistical significance. Moreover, the correlational results show a moderate relationship between normative commitment and achievement culture and a weak, however, positive relationship between achievement and continuance commitment $(r=0.459 ; p=0.115)$ and $(r=130 ; p=0.493)$, respectively. This indicates that there is no significant relationship between achievement culture and all the three facets of organizational commitment. Thus, the adjustment of the culture construct will not necessarily affect the commitment levels on employees in this institution. In this case we accept that there is a relationship between achievement culture and all three facets of organizational commitment, however, not significant.

Lastly, the study revealed that there is less significant relationship between support culture and affective commitment $(r=0.290 ; p=0.120)$. Thus, the change in support culture does not affect affective commitment of the employees at the selected department at the institution. Interestingly, the study further showed that normative commitment and support culture have indirect relationship $(r=-0.721 ; p=0.011)$. Thus, the increase in either, will result in the decrease of the other. Hence, when support culture is to be enhanced in the organization, normative commitment will depreciate. Additionally, support culture in this department/ school at the selected institution has positive strong and significant relationship with continuance commitment $(r=0.882 ; p=0.004)$. Thus, when support culture is cherished and nurtured and as a result grows, continuance culture will also increase in the organization. Given the results, we thus accept the presumption that there is relationship between support culture and normative, continuance and affective commitment.

\section{LIMITATIONS OF THE STUDY}

As indicated earlier, the researcher distributed fifty questionnaires and a 60 per cent response rate was achieved. This meant that the study did not achieve its anticipated and target sample size. The limited sample size was dealt with by the random selection of participants in the study per various departments, which made it easier for the study to bear much weight on its findings.

\section{CONCLUSION AND RECOMMENDATIONS}

Given the above results, one can conclude that culture constructs affect commitment facets in various different ways. This is shown by the complexity and the variation of the results with one culture construct having a different effect on each of the organizational commitment facets. Therefore, based on these findings and other literature studies, it is wise for an institution to diagnose its own culture and verify how it affects its specific employees' and organizational commitment. This will give the institution an overview of their employees' behavior under certain circumstances, hence, adjust their circumstances based sole on their own organizational merits. In conclusion, there is no one size fit all on the effects of culture on organizational commitment, it clearly based on the type of employees, the nature of the business and the environment in which the company or business operates. 


\section{REFERENCES}

1. Allen, N. J., \& Meyer, J. P. (1990). The measurement and antecedents of affective, continuance and normative commitment to the organisation. Journal of Occupational Psychology, 63(1), 1-18. Retrieved from https://goo.gl/aQS5H9

2. Asthana, H. S., \& Bhushan, B. (2016). Statistics for social sciences (with SPSS applications). PHI Learning Pvt. Ltd.

3. Black, R. J. (2004). Organizational culture. Creating the influence needed for strategic success. Core Draw.

4. Brown, A. D. (1995). Organizational culture. London, UK: Pitman Publishing.

5. Bulach, C., Lunenburg, F., \& Potter. (2012). Creating a future of high performing schools; a comprehensive approach to school reform (2nd ed.). Lanham, MD: Rowan and Littlefield.

6. Chatman, J., \& John, K. (1994). Assessing the relationship between industry characteristics and organizational culture: How different can you be? Academy of Management Journal, 37, 522-553. Retrieved from http://citeseerx. ist.psu.edu/viewdoc/download?d oi $=10.1 \cdot 1.466 .3338 \&$ rep $=$ rep $1 \& t$ ype $=$ pdf

7. Collis, J., \& Hussey, R. (2013). Business research: A practical guide for undergraduate and postgraduate students (4th ed.). Hampshire, UK: Palgrave Macmillan.

8. Coyle-Shapiro, J. A., Morrow, C. P., \& Kessler, I. (2006). Serving two organizations: exploring the employment relationship of contracted employees. Human Resource Management, 45(4), 561583. Retrieved from http://onlinelibrary.wiley.com/doi/10.1002/ hrm.20132/abstract

9. Grebe, E. R. (1997). Culture as a transformative agent in a tertiary institution. Journal of Cross Cultural Psychology, 38(1), 10-30.
10. Ranking of universities. (n.d). Retrieved from en.m.wikipedia. org Rankings of universities in South Africa.

11. Handy, C. (1993). Understanding Organisations. London, UK: Penguin.

12. Harmse, L. M. (2001).The influence of organisational culture on job satisfaction and organizational commitment. Unpublished thesis for Bachelor of Commerce. Port Elizabeth: University of Port Elizabeth.

13. Harrison, R. (1972). Understanding your organization's character. Harvard Business Review May-June.

14. Harrison, R. (1993). Diagnosing organisational culture: Trainer's manual. New York: Pfeiffer and Company.

15. Harrison, R., \& Stokes, H. (1992). Diagnosing Organisational Culture. New York: Pfeiffer and Company.

16. Hellriegel, D., Jackson, S. E., Slocum, J., Staude, G., Amos, T., Klopper, H. B., Louw, L., \& Oosthuizen, T. (2004). Management (2nd ed.). Cape Town: Oxford University Press Southern Africa.

17. Higher Education. (2015, May 30). Discussion paper prepared for the second national Higher Education Transfromation Summit. (T. i. Education, Producer). Retrieved from www.gov.za

18. Hofstede, G. (1980). Culture's Consequences: International Differences in Work-Related Values. Beverly Hills, CA: Sage.

19. Hofstede, G. (2001). Culture's consequences: comparing Values, Behaviours, Institutions and Organisations across Nations.

20. Hofstede, G. (2000). Culture's Consequences: International Differences in Work Related Values. Beverly Hills, CA: Sage Publications.

21. Hofstede, G. (2005). Culture's Consequences (2nd ed.). London, UK: SAGE Publication limited.
22. Huey Yiing, L., \& Bin Ahmad, K. Z. (2009). The moderating effects of organizational culture on the relationships between leadership behavir and organizational commitment and between organizational commitment and job satisfaction and performance. Leadership \& Organization Development Journal, 53-86. https://doi. org/10.1108/01437730910927106

23. Kandula, S. R. (2006). Performance Management. New Delhi: Prentice Hall of India private limited.

24. Kessuwan, K., \& Muenjohn, N. (2010). Employee satisfaction: work-related and personal factors. International Review of Business Research Papers, 6(3), 168-177.

25. Lim, B. (n.d.). Examining the Organisation Culture and Organisation Performance. Leadership \& Organisation Development Journal, 2, 1621. Retrieved from http:// www.emeraldinsight.com/doi/ abs/10.1108/01437739510088491

26. Limpanitgul, T., Boonchoo, P., \& Photiyarach, S. (2014). Coworker support and organisational commitment: A comparative study of Thai employees working in Thai and American airlines. Journal of Hospitality and Tourism Management, 21, 100107. https://doi.org/10.1016/j. jhtm.2014.08.002

27. Leskaj, E., Lipi, I., \& Ramaj, R. (2013). Features of Organizational Culture and Their Impact on Banking System Performance. International Journal of Economic Practices and Theories, 3(4), 2247-7225. Retrieved from https://goo.gl/h5B5RJ

28. Lo, M. C., Ramayah, T., Min, H. W., \& Songan, P. (2010). The relationship between leadership styles and organizational commitment in Malaysia: Role of leader-member exchange. Asia Pacific Business Review, 16(1), 79-103.

29. Manetje, O., \& Martins, N. (2009). The relationship between organisational culture and organisational commitment. Unpublished Thesis. 
30. Mathieu, J. E., \& Zajac, D. M. (1994). A review and metaanalysis of the antecedents, correlates and consequences of organizational commitment. Psychological Bulletin, 108(2), 171-194.

31. Mertens, D. M. (2014). Research and evaluation in education and psychology: Integrating diversity with quantitative, qualitative, and mixed methods (4th ed.). Los Angeles: Sage publications.

32. Ministry of Education. (2002). Transformation and Restructuring: A New Institutional Landscape for Higher Education. Department of Higher Education and Training.

33. Mitic, S., Vukonjanski, J., Terek, E., Gligorovic, B., \& Zoric, K. (2016). Organizational culture and organizational commitment: Serbian Case. Journal of Engineering Management and Competitiveness, 6(1), 21-27. Retrieved from http://www.tfzr.rs/ jemc/files/Vol6No1/V6N12016-03. pdf

34. Mullins, L. (1999). Management and Organizational Behavior. 5th Edition. Portsmouth: Pitman Publishing.

35. Meyer, J. P., Hecht, T. D., Gill, H., \& Toplonytsky, L. (2010). Person - organization (culture) fit and employee commitment under conditions of organizational change: A longitudinal study. Journal of Vocational Behavior, 76(3), 458-473.

36. Nel, P., Werner, A., Botha, C., Du Plessis, A., Mey, M., Ngalo, O., Poisat, P., \& Van Hoek, L. (2014). Human Resources Management (9th ed.). Oxford, Southern Africa.

37. Ng’ang'a, J. M., \& Nyongesa, J. W. (2012). The Impact of Organisational Culture on Performance of Educational Institutions. International Journal of Business and Social Science, 3(8), 211-216. Retrieved from http://ijbssnet.com/journals/ Vol_3_No_8_Special_Issue_ April_2012/24.pdf

38. Okechukwu Agwu. (2013). Organizational Culture and Employees Commitment in
Bayelsa State Civil Service. Journal of Management Policies and Practices, 1(1), 35-45.

39. Olanipekun, A.I.O.A., \&AbiolaFalemu, J. (2013). Effects of Organisational Culture on the Performance of Quantity Surveying Firms in Nigeria. International Journal of Humanities and Social Science, 3(5), 45-60.

40. Othman, J., Mohammed, A. K., \& D’Silva, L. J. (2012). Does a Transformational and Transactional Leadership Style Predict Organizational Commitment among Public University Lecturers in Nigeria? Asian Social Science, 165-170.

41. Özşahin, M., Zehir, C., Acar A. Z., \& Sudak, M. K. (2013). The Effects of Leadership and Market Orientation on Organizational Commitment. Social and Behavioural Sciences, 99(6), 363 372. https://doi.org/10.1016/j. sbspro.2013.10.504

42. Prosci, (2010). Definition and scope of change management. Prosci change management webinars.

43. Punch, K. F. (2005). Introduction to Social Research: Quantitative and Qualitative Approaches (2nd ed.). London, UK: SAGE Publications Ltd.

44. Rehman, U. E. (2012). Effects of organisational culture on organisational performance. VU Pakistan.

45. Riketta, M. (2002). Attitudinal organizational commitment and job performance: a meta-analysis. Journal of Organisational Behavior, 23, 257-266. Retrieved from http://onlinelibrary.wiley.com/ doi/10.1002/job.141/abstract

46. Schein, E. H. (2010). Organizational culture and leadership (4th ed.). San Francisco: Jossey Bass.

47. Sekaran, U. (1992). Research methods for business: A skill building approach (2nd ed). New York: John Wiley \& Sons.

48. Shahid, A., \& Azhar, S. M. (2013). Gaining Employee Commitment: Linking to Organisational Effectiveness. Journal of Management Research, 5(1), 250-
268. Retrieved from http://www. macrothink.org/journal/index. $\mathrm{php} / \mathrm{jmr} /$ article/view/2319

49. Singh, H. (2011). Organizational behavior. New Delhi: VK Publications.

50. Sudan, A. S., \& Kumar, N. (2004). Organization effectiveness and change. New Delhi: Anmol.

51. Suppiah, V., \& Sandhu, M. S. (2012). Organizational Culture's Influence on Tacit Knowledge Sharing Behavior. Journal of Knowledge Management, 15(3), 462-477. https://doi. org/10.1108/13673271111137439

52. Tolentino, R. C. (2013). Organizational Commitment and Job Performance of the Academic and Administrative Personnel. International Journal of Information Technology and Business Management, 15(1). Retrieved from http://www.jitbm. com/JITBM\%2015th\%20volume/5\%20Organization\%20Commitment.pdf

53. Van Stuyvesant Meijen, J. (2007). The influence of organisational culture on organisational commitment at a selected local municipality.

54. Watson, T. J. (2002). Organising and Managing work:

Organisational, Managerial and Strategic Behavior in Theory and Practice. Harlow: Pearson Education.

55. Zhu, C. Devos, G., \& Fei, L. Y. (2011). Teacher perceptions of school culture and their organizational commitment and well-being in a Chinese school. Asia Pacific Education Review, 12, 319-328. 